\title{
Analysis of User Requirements Gathering Practices in Agile and Non-Agile Software Development Team
}

\author{
Sunaina Ghai \\ Department of computer science \\ Punjabi university regional campus, mohali
}

\author{
Jagpuneet Kaur \\ Assistant professor \\ Punjabi university, patiala
}

\begin{abstract}
Software engineering is continuously gaining success day by day. In last decades a lot of growth has been observed in the software industry. Various new software development methodologies are introduced such as agile software development with increasing demand of software industry. In all these development methodologies, user requirements play an important role for completion of the successful project. If requirements are not clear it can be the reason of project failure. Now a day's some industries are not aware about the right way to collect and fulfill the requirements. This survey based study focused on the analysis of user requirements gathering practices in agile and non-agile software development teams. Main purpose of this study is to analyze the factors involved in requirements gathering practices and rate of maximum agility in tri-city (Mohali, Chandigarh and Panchkula) on the basis of different work experiences.
\end{abstract}

\section{General Terms}

Agile requirements engineering, chi-square test, agility.

\section{Keywords}

Software Developments, Requirements Engineering, Requirements Analysis, User Requirements Analysis.

\section{INTRODUCTION}

Software engineering is the very integrated part of the industry from mid nineties. Software industry became significant economical activity from the last few decades. Developing the software is error prone because of many labor-intensive activities. Every year there are more softwarebased devices controlling functions that are critical to human survival. The chances of disasters and failures of these software-based devices have greatly increased.

In 1995, Standish Group published a survey report called 'chaos report'. The failure rate of all type of companies is presented in this report. This rate is mentioned in below points [2].

- Only 9\% of projects in large companies were successful, compared to $16.2 \%$ for medium companies and $28 \%$ for small companies.

- $61.5 \%$ of large company projects were challenged, compared to $46.7 \%$ for medium companies and $50.4 \%$ for small companies.

- $29.5 \%$ projects were cancelled in large companies, compared to $37.1 \%$ for medium companies and $21.6 \%$ for small companies.

- For every 100 projects that start, there are 94 projects restarts.

\subsection{Problem definition}

Effectively gathering user requirements is a critical first step of any project and perhaps one of the most challenging project management skills. Focus of study is on the analysis of user requirements gathering in agile and non-agile software development teams. It has been made possible by conducting a survey with questionnaires, and analyzing the rate of agility on the basis of responses given by of various respondents.

\subsection{Evolution}

Waterfall model was being followed where requirements are fixed and the next phase starts when the earlier one are finished. It represents the most widely accepted traditional developmental method. Evolutionary model and spiral model are proposed to overcome the limitation of waterfall model where prototype is first made and then that is converted to the working software. But the common limitation of all is that, at later phases no process is able to handle the change of requirements. Then, agile software development is proposed to overcome the limitation of all models that was to handle the change in requirements at later phases.

\subsection{Purpose of the study}

The main purpose of the study is to analyze the role of user requirements gathering practices in agile and non-agile software development teams. The study is divided into two consecutive steps:

I. Identify the factors involved in the various practices of requirements analysis

II. Analyze the rate of agile and traditional requirement gathering practices empirically on the basis of different work experiences.

\subsection{Contributions of this study}

The main contributions of this study are highlighted in the following points. Beneficiary of our findings are:

- Agile organizations: It helps various organizations to understand the factors affecting requirements analysis procedure.

- Requirement analysts: Analysts also plays an important role in requirement analysis. It is the role of the project manager or business analyst to ask the right questions and communicate effectively with all stakeholders.

\section{REQUIREMENTS ENGINEERING}

$\mathrm{RE}$ basically consists of discovering, analyzing and documenting the requirements of the system. Requirement engineering is important activity of the project because it uncovers and analyses various future problems which can become a cause of failure of the project. As it is also analyzed 
that $37 \%$ of the problems occurred in the development of challenging systems are related to the Requirement phase [14].

Conceptually, requirements engineering includes three types of activity mainly eliciting requirements, analyzing requirements, recording requirements.

\section{RESEARCH METHODOLOGY}

To achieve the set objectives, a questionnaire was framed by taking care of the agile principles So the questionnaire not only takes part in research but also makes publicity of user requirement gathering practices to those who are not aware about agile requirements gathering practices. Respondents were contacted by direct mailing and they were offered personal appointments to fill out questionnaires. They could choose to have the company data processes anonymously. Descriptive statistics tools (mean, frequency) and chi-square test are the tools which have been used to comprehend the collected data into meaningful form. However, reliability of the questionnaire also be judged by using existing statistical tests.

\section{ANALYSIS OF DATA, RESULTS AND DISCUSSIONS}

The raw data for the study was obtained with the help of a survey. In order to screen the data for meaningful purposes, the data was analyzed by using statistical tools like descriptive statistics (mean, frequency) and chi square test.

\subsection{Reliability of the data}

Reliability of the data is to be calculated by finding the value of coefficient of reliability that is Cronbach's alpha. It was calculated with the help of statistical tool SPSS.

Table 4.1 Reliability value

\begin{tabular}{|c|c|}
\hline Coefficient of reliability & $\begin{array}{c}\text { Value of coefficient of } \\
\text { reliability }\end{array}$ \\
\hline Cronbach's alpha & 0.745 (Acceptable) \\
\hline
\end{tabular}

\subsection{Data analysis}

The results were obtained using descriptive statistics, chisquare test, keeping in view the nature and objective of the study.

\subsubsection{SECTION A}

This section consists of the organization's information covered for this survey it includes representation of organization domain, number of employees, work experience of respondents and annual turnover of the organization. 30 respondents were responded the questionnaire.

Table 4.2 Statistics of respondents

\begin{tabular}{|c|c|c|c|c|}
\hline & $\begin{array}{c}\text { Organi } \\
\text { zation } \\
\text { domain }\end{array}$ & $\begin{array}{l}\text { No. of } \\
\text { employees }\end{array}$ & $\begin{array}{c}\text { Work } \\
\text { exper- } \\
\text { ience }\end{array}$ & $\begin{array}{c}\text { Annual } \\
\text { turnover of } \\
\text { organiz- } \\
\text { ations }\end{array}$ \\
\hline $\begin{array}{c}\text { N } \\
\text { Valid }\end{array}$ & 30 & 30 & 30 & 30 \\
\hline $\begin{array}{c}\text { Missi } \\
\text { ng }\end{array}$ & 0 & 0 & 0 & 0 \\
\hline
\end{tabular}

Where $\mathrm{N}$ is number of respondents

Table 4.2 gives the statistics of number of respondents of questionnaire. This statistics shows that the 30 respondents answered for this survey. All of the 30 respondents respond for every questions included in organization information section. The details of the every question are represented in the form of table and pie chart representation below.

1. Organization domain representation:

Table 4.3 Domain representation of organizations

\begin{tabular}{|l|c|c|c|c|}
\hline Options & Frequency & $\%$ & $\begin{array}{c}\text { Valid } \\
\%\end{array}$ & $\begin{array}{c}\text { Cumulative } \\
\%\end{array}$ \\
\hline $\begin{array}{l}\text { Software } \\
\text { develop } \\
\text { ment }\end{array}$ & 5 & 16.667 & 16.667 & 16.667 \\
\hline $\begin{array}{l}\text { Multiple } \\
\text { domains }\end{array}$ & 25 & 83.333 & 83.333 & 100 \\
\hline
\end{tabular}

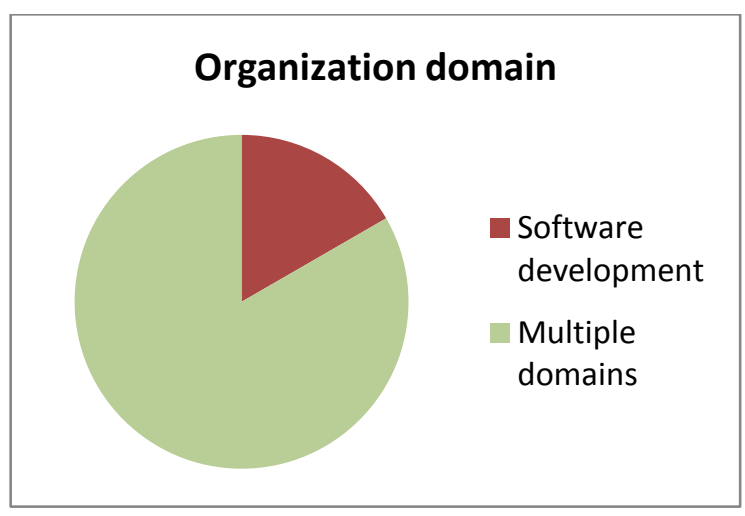

Figure 4.1 Organization domain

As can be seen both from the table and chart given above, $17 \%$ of the respondents surveyed belong to organizations working in software development only and $83 \%$ of the respondents surveyed belongs to organizations working in multiple domains.

2. Number of employees representation:

Table 4.4 Number of employees

\begin{tabular}{|l|c|c|c|c|}
\hline Options & Frequency & $\%$ & $\begin{array}{c}\text { Valid } \\
\%\end{array}$ & $\begin{array}{c}\text { Cumulative } \\
\%\end{array}$ \\
\hline $0-50$ & 16 & 53.333 & 53.333 & 53.333 \\
\hline $50-500$ & 10 & 33.333 & 33.333 & 86.666 \\
\hline $500-1000$ & 3 & 10 & 10 & 96.666 \\
\hline $\begin{array}{l}\text { Over } \\
1000\end{array}$ & 1 & 3.334 & 3.334 & 100.00 \\
\hline
\end{tabular}




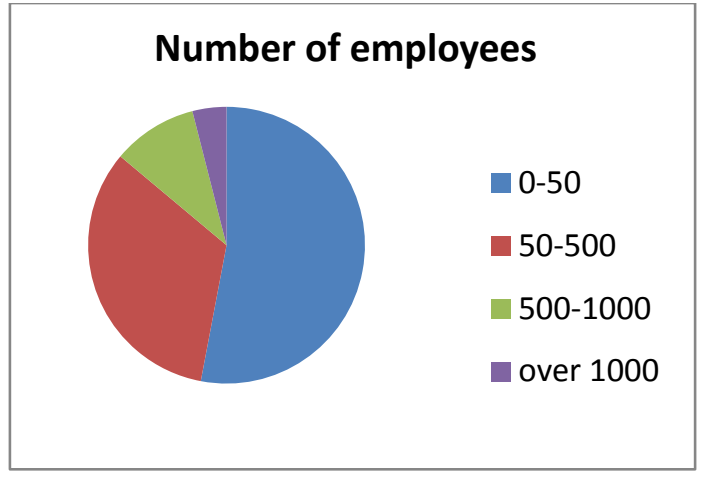

Figure 4.2 Number of employees

As can be seen both from the table and chart given above, $53.333 \%$ of the respondents belongs to organizations having 0-50 employees , $33.333 \%$ having 50-500 employees, $10 \%$ having 500-1000 employees and $3.334 \%$ belongs to organization having more than 1000 employees.

3. Work experience:

Table 4.5 Work experience of respondents

\begin{tabular}{|c|c|c|c|c|}
\hline $\begin{array}{c}\text { Option } \\
\text { s }\end{array}$ & Frequency & $\%$ & $\begin{array}{c}\text { Valid } \\
\%\end{array}$ & $\begin{array}{c}\text { Cumulative } \\
\%\end{array}$ \\
\hline $0-5$ & 17 & 56.667 & 56.667 & 56.667 \\
\hline $5-10$ & 11 & 36.667 & 36.667 & 93.334 \\
\hline $10-15$ & 2 & 6.666 & 6.666 & 100.00 \\
\hline
\end{tabular}

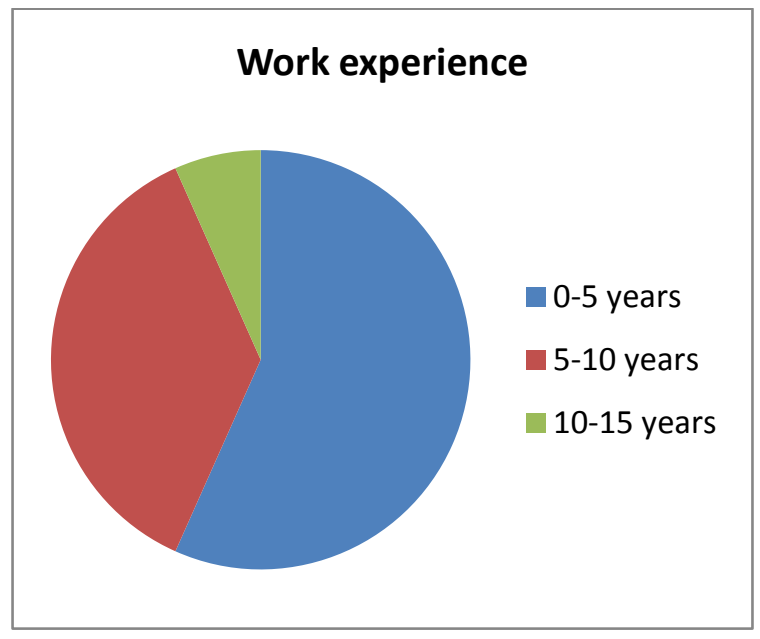

Figure 4.3 Work experience

As can be seen both from the table and chart given above, $56.667 \%$ of the respondents belongs to organizations having experience of 0-5 years, $36.667 \%$ having experience of 5-10 years and $6.666 \%$ having experience of $10-15$ years

4. Annual turnover of organizations:
Table 4.6 Annual turnovers of organizations

\begin{tabular}{|c|c|c|c|c|}
\hline Options & Frequency & $\%$ & $\begin{array}{c}\text { Valid } \\
\%\end{array}$ & $\begin{array}{c}\text { Cumulative } \\
\%\end{array}$ \\
\hline $\begin{array}{c}1-25 \\
\text { millions }\end{array}$ & 25 & 83.334 & 83.334 & 83.334 \\
\hline $\begin{array}{c}25-50 \\
\text { millions }\end{array}$ & 4 & 13.333 & 13.333 & 96.667 \\
\hline $\begin{array}{c}\text { more } \\
\text { than 75 } \\
\text { millions }\end{array}$ & 1 & 3.333 & 3.333 & 100 \\
\hline
\end{tabular}

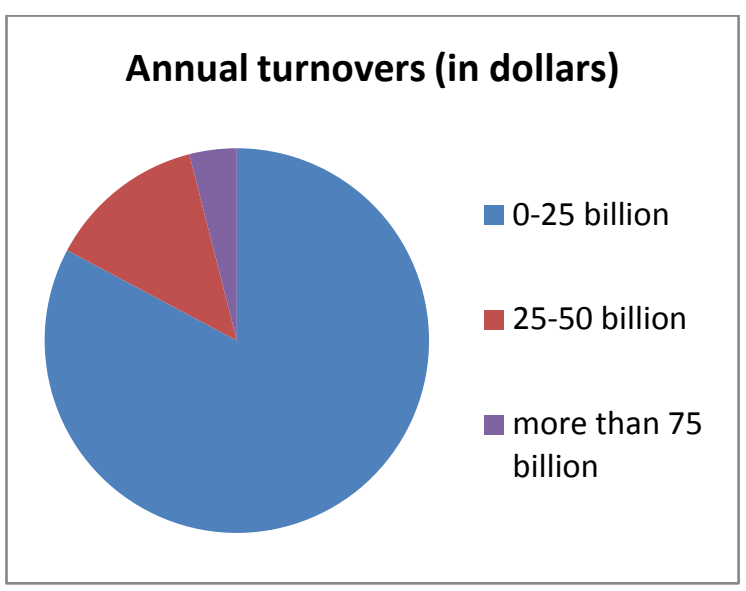

Figure 4.4 Annual turnovers

As can be seen both from the table and chart given above, $83.334 \%$ of the respondents belongs to organizations having annual turnover 0-25 billion dollars, $13.333 \%$ of the respondents belongs to organizations having annual turnover 25-50 million dollars and 3.333\% of the respondents belongs to organizations having annual turnover more than 75 million dollars.

\subsubsection{SECTION A}

It includes the analysis of agile perceptions.

\subsubsection{Chi-square test}

A chi square $\left(X^{2}\right)$ statistic is used to investigate whether distributions of categorical variables differ from one another. This test allows us to compare a collection of categorical data with some theoretical expected distribution.

Setting of hypothesis:

- H0: Two categorical variables (responses and work experience) are independent.

- Ha: Two categorical variables (responses and work experience) are dependent.

Testing of hypothesis:

Test of hypothesis is shown in table 5.5 below. Hypothesis is being tested with $5 \%$ level of significance. If the calculated value of chi-square test is greater than the value at $5 \%$ level of significance, the null hypothesis will be rejected and alternative hypothesis is accepted. Otherwise the null hypothesis is accepted. 
Table 4.7 Categorical data set

\begin{tabular}{|l|l|l|l|l|l|l|l|l|}
\hline & R1 & R2 & R3 & R4 & R5 & R6 & R7 & T \\
\hline W1 & 11 & 250 & 100 & 23 & 16 & 11 & 0 & 510 \\
\hline W2 & 86 & 162 & 63 & 6 & 7 & 6 & 0 & 330 \\
\hline W3 & 10 & 24 & 16 & 5 & 4 & 0 & 1 & 60 \\
\hline T & 206 & 436 & 179 & 34 & 27 & 17 & 1 & 900 \\
\hline
\end{tabular}

Where RX: Type X response (where $X=1,2,3,4,5,6,7$ )

T: Totals.

W1: Work experience (0-5 years).

W2: Work experience (5-10 years).

W3: Work experience (10-15 years).

Table 4.8 Chi-square test

\begin{tabular}{|c|c|c|c|c|c|}
\hline $\mathbf{N}$ & $\mathbf{O}$ & $\mathbf{E}$ & $|\mathbf{O}-\mathbf{E}|$ & $\mid$ O-E $\mid 2$ & $(|\mathrm{O}-\mathrm{E}| 2) / \mathrm{E}$ \\
\hline 1 & 110 & 116.7 & 6.7 & 44.89 & 0.385 \\
\hline 2 & 250 & 247 & 3 & 9 & 0.036 \\
\hline 3 & 100 & 101.4 & 1.4 & 1.96 & 0.019 \\
\hline 4 & 23 & 19.2 & 3.8 & 14.44 & 0.752 \\
\hline 5 & 16 & 15.3 & 0.7 & 0.49 & 0.032 \\
\hline 6 & 11 & 9.6 & 1.4 & 1.96 & 0.204 \\
\hline 7 & 0 & 0.6 & 0.6 & 0.36 & 0.6 \\
\hline 8 & 86 & 75.5 & 10.5 & 110.25 & 1.46 \\
\hline 9 & 162 & 159.8 & 2.2 & 4.84 & 0.03 \\
\hline 10 & 63 & 65.6 & 2.6 & 6.76 & 0.103 \\
\hline 11 & 6 & 12.5 & 6.5 & 42.25 & 3.38 \\
\hline 12 & 7 & 9.9 & 2.9 & 8.41 & 0.849 \\
\hline 13 & 6 & 6.2 & 0.2 & 0.04 & 0.006 \\
\hline 14 & 0 & 0.4 & 0.4 & 0.16 & 0.4 \\
\hline 15 & 10 & 13.7 & 3.7 & 13.69 & 0.99 \\
\hline 16 & 24 & 29 & 5 & 25 & 0.862 \\
\hline 17 & 16 & 11.9 & 4.1 & 16.81 & 1.413 \\
\hline 18 & 5 & 2.3 & 2.7 & 7.29 & 3.17 \\
\hline 19 & 4 & 1.8 & 2.2 & 4.84 & 2.689 \\
\hline 20 & 0 & 1.1 & 1.1 & 1.21 & 1.1 \\
\hline 21 & 1 & 0.06 & 0.94 & 0.8836 & 14.727 \\
\hline $\mathrm{T}$ & & & & & 33.207 \\
\hline
\end{tabular}

Where, $\mathrm{O}$ is observed frequency.

$\mathrm{E}$ is expected frequency.

$\mathrm{T}$ is total.

$\mathrm{N}$ is serial number.

Chi-square $=33.207$

Degrees of freedom $=(7-1) *(3-1)$

Degrees of freedom $=12$

Reject Ho because 33.207 is greater than 21.03 (for alpha = 0.05).Thus, we would reject the null hypothesis that responses and work experience are independent. Testing of hypothesis shows that that response can vary with work experience. This means that the knowledge of agile requirements analysis varies with work experience of respondents.

\subsubsection{Overall maximum agility in tri-city on the} basis of different work experiences

As 1 (Strongly agree) as the highest priority value for agile in scale 1-7, for which the value of mean comes out to be 4 . As moving towards 1 mean value will gradually decrease from 4 , so less the value of mean more will be the better solution for agile. Zero response is invalid and cannot be considered as part of validation.

According to the various responses given by the respondents, overall maximum agility on the basis of different work experiences is to be calculated as given below.

Table 4.9 Overall maximum agility with $(0-5)$ work experience

\begin{tabular}{|l|c|c|c|c|}
\hline \multicolumn{1}{|c|}{ Options } & Frequency & OF & OF & $\begin{array}{l}\text { Weighted } \\
\text { mean }\end{array}$ \\
\hline $\begin{array}{l}7 \text { Strongly } \\
\text { disagree }\end{array}$ & 0 & $7 * 0$ & 0 & Not valid \\
\hline 6 Disagree & 11 & $6 * 11$ & 66 & $\begin{array}{c}1148 / 66 \\
=17.393\end{array}$ \\
\hline $\begin{array}{l}\text { 5 Disagree } \\
\text { somewhat }\end{array}$ & 16 & $5 * 16$ & 80 & $\begin{array}{c}1148 / 80 \\
=14.35\end{array}$ \\
\hline $\begin{array}{l}4 \\
\text { Undecided }\end{array}$ & 23 & $4 * 23$ & 92 & $\begin{array}{c}1148 / 92 \\
=12.478\end{array}$ \\
\hline $\begin{array}{l}3 \text { Agree } \\
\text { somewhat }\end{array}$ & 100 & $3 * 100$ & 300 & $\begin{array}{c}1148 / 300 \\
=3.826\end{array}$ \\
\hline 2 Agree & 250 & $2 * 250$ & 500 & $\begin{array}{c}1148 / 500 \\
=2.296\end{array}$ \\
\hline $\begin{array}{l}\text { 1 Strongly } \\
\text { agree }\end{array}$ & 110 & $1 * 110$ & 110 & $\begin{array}{c}1148 / 110 \\
=10.436\end{array}$ \\
\hline Total & & 1148 & \\
\hline
\end{tabular}

Where OF is observed frequency

According to responses given by all respondents from tri-city, 2.296 is the minimum weighted mean. Therefore overall maximum agility can be calculated.

Overall agility $=[(7-2.296) / 7] * 100$

$$
=67.2 \%
$$


Table 4.10 Overall maximum agility with $(5-10)$ work experience

\begin{tabular}{|c|c|c|c|c|}
\hline Options & Frequency & OF & OF & $\begin{array}{c}\text { Weighted } \\
\text { mean }\end{array}$ \\
\hline $\begin{array}{c}\text { 7 Strongly } \\
\text { disagree }\end{array}$ & 0 & $7 * 0$ & 0 & Not valid \\
\hline 6 Disagree & 6 & $6 * 6$ & 36 & $\begin{array}{c}694 / 36 \\
=19.277\end{array}$ \\
\hline $\begin{array}{c}\text { 5 Disagree } \\
\text { somewhat }\end{array}$ & 7 & $5 * 7$ & 35 & $\begin{array}{c}694 / 35 \\
=19.828\end{array}$ \\
\hline $\begin{array}{c}\text { Undecided } \\
\text { 3 Agree } \\
\text { somewhat }\end{array}$ & 63 & $3 * 63$ & 189 & $\begin{array}{c}694 / 189 \\
=3.672\end{array}$ \\
\hline $\begin{array}{c}\text { 2 Agree } \\
\text { Agmgly }\end{array}$ & 162 & $2 * 162$ & 324 & $\begin{array}{c}694 / 324 \\
=2.1419\end{array}$ \\
\hline $\begin{array}{c}\text { 1 Strongly } \\
\text { agree }\end{array}$ & 86 & $1 * 86$ & 86 & $\begin{array}{c}694 / 86 \\
=8.069\end{array}$ \\
\hline Total & 6 & 694 & \\
\hline
\end{tabular}

Where OF is observed frequency.

According to responses given by all respondents from tri-city, 2.1419 is the minimum weighted mean. Therefore overall maximum agility can be calculated as below.

Overall agility $=[(7-2.1419) / 7] * 100$

$$
=69.4 \%
$$

Table 4.11 Overall maximum agility with (10-15) work experience

\begin{tabular}{|c|c|c|c|c|}
\hline Options & Frequency & OF & OF & $\begin{array}{c}\text { Weighted } \\
\text { mean }\end{array}$ \\
\hline $\begin{array}{l}7 \text { Strongly } \\
\text { disagree }\end{array}$ & 1 & $7 * 1$ & 7 & $\begin{aligned} & 153 / 7 \\
= & 21.857\end{aligned}$ \\
\hline 6 Disagree & 0 & $6 * 0$ & 0 & Not valid \\
\hline $\begin{array}{l}5 \text { Disagree } \\
\text { somewhat }\end{array}$ & 4 & $5 * 4$ & 20 & $\begin{array}{l}153 / 20 \\
=7.65\end{array}$ \\
\hline 4 Undecided & 5 & $4 * 5$ & 20 & $\begin{array}{l}153 / 20 \\
=7.65\end{array}$ \\
\hline $\begin{array}{l}3 \text { Agree } \\
\text { somewhat }\end{array}$ & 16 & $\begin{array}{c}3 * 1 \\
6\end{array}$ & 48 & $\begin{array}{l}153 / 48 \\
=3.187\end{array}$ \\
\hline 2 Agree & 24 & $\begin{array}{c}2 * 2 \\
4\end{array}$ & 48 & $\begin{array}{l}153 / 48 \\
=3.187\end{array}$ \\
\hline $\begin{array}{l}1 \text { Strongly } \\
\text { agree }\end{array}$ & 10 & $\begin{array}{c}1 * 1 \\
0\end{array}$ & 10 & $\begin{array}{l}153 / 10 \\
=15.3\end{array}$ \\
\hline Total & & & 153 & \\
\hline
\end{tabular}

Where OF is observed frequency.

According to responses given by all respondents from tri-city, 3.187 is the minimum weighted mean. Therefore overall maximum agility can be calculated as below.

Overall agility $=[(7-3.187) / 7] * 100$

$$
=54.47 \%
$$

From the above calculated values of agility in tri-city it is clear that all software development firms which are surveyed following agile practices along with other practices. With the various successful features of agile, companies are moving towards the agile at faster rate but these have some traditional features also. So there is a hybrid environment analyzed in software development firms of tri-city. And rate of agile adoption is increasing day by day.

\section{CONCLUSION}

It is clear that all software development firms which are surveyed follow agile practices along with other practices. With the various successful features of agile, companies are moving towards the agile at a faster rate but these have some traditional features also. So there is a hybrid environment analyzed in software development firms of tri-city. The rate of agile adoption is increasing day by day. Rate of maximum agility with varying work experience is calculated. Maximum agility is analyzed in tri-city of respondents having experience $10-15$ years.

\section{ACKNOWLEDGEMENTS}

I would like to place on record my deep sense of gratitude to people who helped and supported me in my work.I express my sincere gratitude to Ms. Jagpuneet kaur, Assistant professor ,Department of computer science, Punjabi University, Patiala for guiding me with attention and care. She has taken pain to go through the work and make necessary corrections when needed. Most importantly, I would like to thank my parents and the Almighty for showing me the right direction, to help me stay calm and keep moving even at times when there was no hope.

\section{REFERENCES}

[1] Fayad, M. E., Laitinen, M., \& Ward, R. P., "Software engineering in the small", Communications of the ACM, vol. 43(3), pp. 115-118, 2000.

[2] The Standish Group, The Chaos report, http://www.projectsmart.co.uk/docs/chaos-report.pdf (dated 8/Jan/2010).

[3] Version one, 3rd Annual Survey: "The State of Agile Development",http://www.Versionone.com/pdf $/ 3^{\text {rd }}$ AnnualStateOfAgile_FullDataReport.pdf, 2008.

[4] M. Huo, J. Verner, L. Zhu \& M.A. Babar, "Software quality and agile methods" presented at the COMPSAC '04: Proceedings of the $28^{\text {th }}$ Annual International Computer Software and Applications Conference, pp. 520-525, 2004.

[5] W. W. Royce, "Managing the Development of Large Software Systems", in the Proceedings of $9^{\text {th }}$ International Conference Software Engineering, IEEE Computer Society, pp. 328-338, 1987.

[6] F. Paetsch, A. Eberlein \& F. Maurer, "Requirements engineering and agile software development", $12^{\text {th }}$ IEEE International Workshop on Enabling Technologies: 
Infrastructure for Collaborative Enterprises, pp. 308-313, June 2003.

[7] Andrea De Lucia \& Abdallah Qusef, "Requirement engineering in agile software development", journal of emerging technologies in web intelligence, vol. 2(3), pp. 212-220, August 2010.

[8] S. Powell, F. Keenan, K. McDaid, "Enhancing agile requirements elicitation with personas", IADIS International journal on computer science and information systems, vol. 2(1), pp. 82-95, 2007.

[9] S. Bhalerao, D. Puntambekar \& M.Ingle, "Generalizing agile software development life cycle", International journal on computer science and engineering, vol. 1(3), pp. 222-226, 2009.

[10] J. Kalermo \& J. Risanen, "Agile software development in theory and practice," M.S. thesis, Department of computer science and information system at University of Jyvaskyla, 2002.

[11] Z. Rachdeva, M. Daneva , A. Herrmann \& R.J. Wieringa, "A conceptual model and process for clientdriven agile requirements prioritization", in the proceedings of the $4^{\text {th }}$ international conference on research challenges in computer science, Nice, France, pp. 287-297, ISBN: 978-1-4244-4840-1, 2010.
[12] M. Maguire \& N. Bevan, "User requirement analysis : a review of supporting methods", proceedings of IFIP 17th world computer congress, Montreal, Canada, pp. 133-148, 25-30 august 2002.

[13] A. chaudhary, A. Punia \& M. Pujar, "Requirements engineering role in agile development", presented at Infosyslabs.[Online].Available:http://www.infosys.com/ Infosyslabs/publications/documents/requirementengineering-agile-development.pdf, 2008.

[14] A. Polini, "Software Requirements", [Online].Available: http:// www1.isti.cnr.it / polini/ lucidiSE / Requirements1.pdf, February 2010.

[15] A. Buchalcevova, "Research of the Use of Agile Methodologies in the Czech Republic", C. Barry, M. Lang, W. Wojtkowski, G. Wojtkowski, S. Wrycza, \& Zupancic, The Inter-Networked World: ISD Theory, Practice, and Education. Springer-Verlag: New York, ISBN 978-0387304038, 2008.

[16] M.A. Awad, "A comparison between agile and traditional software development methodologies", M.S Thesis, University of western Australia, 2005.

[17] Yunyun Zhu, "Requirement engineering in an agile environment", M.S. thesis, Uppsala university, Department of information technology, 2009. 